\title{
PENGARUH RANGGAS PAKSA DAN SUPLEMENTASI TEPUNG BEKICOT TERHADAP PERTUMBUHAN FOLIKEL YOLK AYAM (Gallus turcicus).
}

\author{
Kiptiyah, Hartanto, Lisin \\ UIN Maliki Malang
}

\begin{abstract}
Research is conducted to examine the effect of fast method's forced molting and snail flour supplementation on yolk follicle growth of chicken (Gallus turcicus). In this research, female chicken is used with 1.5 years of age and $1.2 \pm 2 \mathrm{~kg}$ body weight. The treatments include the fast method's forced $f$ molting (without food for 0 hour, 72 hours, and 168 hours, but with drink ad libitum) and snail flour supplements of $6 \%, 12 \%$, and $18 \%$.

The observation is concerned with yolk follicle growth attributes such as ovary weight and yolk follicle sizes, such as large, medium and small. The data obtained is analyzed by ANOVA. Result indicates that the treatment of fast method's forced molting and snail flour supplementation does not have effect on yolk follicle growth of chicken (Gallus turcicus). It is evident as reviewed from the ovary weight and from yolk follicle sizes of large, medium and small. Such phenomena is revealed through data related to fast method's forced molting and snail flour supplementation, in which both are without effect on ovary weight and large follicle size, but with effect on medium and small yolk follicle sizes.
\end{abstract}

Keywords: Chicken, forced molting, snail flour, yolk follicle

\section{PENDAHULUAN}

Ayam (Gallus turcicus) merupakan salah satu jenis ayam yang berpotensi untuk memproduksi telur sekitar 225 butir telur/tahun (Kholis dan Sitanggang, 2002). Ditinjau dari segi morfologi, telur ayam (Gallus turcicus) memiliki kemiripan dengan telur ayam kampung, sehingga cenderung disukai masyarakat. Kenyataannya, produksi telur ayam tersebut mencapai optimal pada umur 8 bulan dan mengalami penurunan pada umur 1,5-2 tahun saat memasuki periode molting (Darmana dan Sitanggang, 2002).

Periode ini berlangsung selama 3-4 bulan (Khajali et al., 2008). Sebenarnya secara alami, hal ini terjadi pada ayam petelur pada akhir periode produksi akibat peningkatan kadar hormon prolaktin pada tubuh ayam (Safitri, 2005; Suprijatna, dkk (2005). Fenomena ini menyebabkan peternak ayam kurang mendapatkan hasil produksi yang optimal, karena kebutuhan pasar yang semakin 
meningkat dan tidak bisa menunggu lama sedangkan produksi telur menurun, oleh karena itu dibutuhkan metode khusus untuk mempersingkat periode molting sehingga ayam lebih cepat bereproduksi.

Untuk mempersingkat periode molthing dilakukan ranggas paksa (forced molting) dengan harapan ayam akan lebih cepat bereproduksi (Khajali et al.,2008). Metode ini sering digunakan oleh industri perunggasan sebagai strategi manajemen yang ekonomis dan efektif (Berry, 2003; Brake et al., 1998; Malik et al., 2008; Webster, 2003). Dari beberapa metode ranggas paksa, yang sering digunakan oleh industri perunggasan adalah metode puasa. (Alodan dan Mashaly, 1999; Oguike et al., 2005; Offiong et al,. 2006; Taixeira et al., 2007).

Akibat ranggas paksa menyebabkan bobot ayam turun 25$30 \%$ akibat regresi dari hati, ovarium, oviduk, jaringan adiposa dan jaringan otot (Berry, 2003; Webster, 2003). Akibat regresi tersebut, pertumbuhan folikel yolk akan terhambat sehingga proses produksi telur akan mengalami hambatan. Proses produksi folikel yolk dapat dipengaruhi oleh asupan protein secara eksogen melalui penambahan protein dalam ransum. Hasil penelitian Hasan et al. (2000) dan Togun et al. (2004) menunjukkan bahwa, penambahan crud protein $16 \%$ pada ransum setelah perlakuan ranggas paksa mampu mempercepat pemulihan bobot badan dan produksi telur lebih cepat.

Salah satu sumber protein hewani yang pernah dijadikan sebagai bahan tambahan ransum adalah tepung bekicot (Achatina fulica). Tepung bekicot mengandung protein kasar $60,9 \%$, dengan penambahan tepung bekicot $25 \%$ pada ransum mampu meningkatkan produksi telur pada puyuh (Sa'adah, 2008). Berkenaan dengan hal tersebut, maka penambahan tepung bekicot pada ransum setelah perlakuan ranggas paksa diduga mampu mempercepat proses regenerasi organ reproduksi yang melibatkan pertumbuhan folikel.

\section{BAHAN DAN METODE}

\section{Bahan}

Bahan yang digunakan dalam penelitian ini adalah ayam betina (Gallus turcicus) yang berumur 1,5 tahun dengan bobot badan 1,2-2 $\mathrm{kg}$ dan tepung bekicot. 
Pengaruh Ranggas Paksa dan Suplementasi ...

\section{Metode}

\section{Persiapan Pakan}

Pakan yang digunakan dalam penelitian ini mengikuti formula yang disusun oleh Sa'dah (2008) berupa tepung yang terdiri dari jagung, bekatul, tepung ikan, bungkil kacang tanah, topmix dan ditambah pakan berupa tepung bekicot.

\section{Pemberian Perlakuan}

Ayam dipuasakan pakan berdasarkan perlakuan yang meliputi kontrol (0 jam), 72 jam, dan 168 jam. Selama puasa (tidak makan) diberi minum secara ad libitum. Setelah perlakuan puasa pakan ayam diberi ransum yang mengandung tepung bekicot berdasarkan perlakuan yaitu $0 \%, 6 \%, 12 \%$ dan $18 \%$ sebanyak $20 \mathrm{~g}$ selama 3 hari kemudian 40 g selama 3 hari kemudian $60 \mathrm{~g}$ selama 3 hari dan dilanjutkan sebanyak 80 g sampai akhir penelitian.

\section{Pengambilan Sampel}

Pembedahan dilakukan setelah 35 hari masa perlakuan seperti yang telah dilakukan oleh Oguike et al (2005) dengan langkah sebagai berikut:

1) Ayam disembelih, dengan cara memotong leher sampai terputus saluran respirasi, pencernaan dan sirkulasi.

2) Ayam dibedah secara vertikal pada daerah abdomen posterior menuju anterior dengan membuka daerah rongga perut dan rongga dada.

3) Ovarium dan oviduk diambil.

4) Hasil yang diperoleh dicatat berdasarkan kelompok perlakuan.

\section{Pengamatan}

1) Ovarium ditimbang menggunakan timbangan digital UWE NJW-300 kapasitas $300 \mathrm{~g}$ dengan tingkat ketelitian $0,01 \mathrm{~g}$.

2) Pertumbuhan folikel yolk diamati dengan menghitung jumlah folikel ovarium berdasarkan kategori ukuran diameter pada setiap ekor ayam yang telah dikelompokkan. Diameter folikel diukur dengan menggunakan jangka sorong, yang dikelompokkan berdasarkan kriteria yang digunakan dalam penelitian Rahman, dkk (1999), terdiri atas ukuran besar $(\geq 15$ $\mathrm{mm})$, sedang $\quad(5,0-14,9 \mathrm{~mm})$, dan ukuran kecil (1,0- 4,9 mm). 
HASIL DAN PEMBAHASAN

1. Hasil

Pengaruh Ranggas Paksa Metode

Puasa dan Suplementasi Tepung

Bekicot pada Ransum terhadap pertumbuhan folikel yolk Ayam (Gallus turcicus)

Berdasarkan hasil penelitian dan analisis statistik dengan ANAVA ganda tentang pengaruh ranggas paksa (forced molting) metode puasa dan suplementasi tepung bekicot (Achatina fulica) pada ransum terhadap pertumbuhan folikel yang meliputi jumlah folikel berukuran besar, sedang, dan kecil tercantum dalam tabel berikut ini.

Tabel 1.1 Ringkasan ANAVA ganda tentang pengaruh ranggas paksa metode puasa dan suplementasi tepung bekicot terhadap bobot ovarium

\begin{tabular}{|c|c|c|c|c|c|}
\hline SK & db & JK & KT & $\begin{array}{c}\text { F } \\
\text { hitung }\end{array}$ & $\begin{array}{c}\mathrm{F} \\
\text { tabel } \\
\mathbf{0 , 0 5}\end{array}$ \\
\hline Ulangan & 3 & 3,34 & 1,11 & $0,38^{\mathrm{tn}}$ & 3,07 \\
\hline Perlakuan: & (7) & $(37,24)$ & 5,32 & $1,84^{\mathrm{tn}}$ & 2,49 \\
\hline $\mathrm{P}$ & 1 & 2,57 & 2,57 & $0,89^{\mathrm{tn}}$ & 4,32 \\
\hline$F$ & 3 & 20,72 & 6,91 & $2,41^{\mathrm{tn}}$ & 3,07 \\
\hline $\mathrm{PF}$ & 3 & 13,95 & 4,65 & $1,61^{\mathrm{tn}}$ & 3,07 \\
\hline Galat & 21 & 60,49 & 2,88 & & \\
\hline Total & 31 & 101,07 & & & \\
\hline
\end{tabular}

Keterangan: tn menunjukkan tidak berbeda nyata
Tabel Ringkasan ANAVA tunggal tentang 1.2 pengaruh durasi puasa terhadap bobot ovarium pada ayam arab

\begin{tabular}{|l|l|l|l|l|l|}
\hline SK & Db & JK & KT & $\begin{array}{l}\text { F } \\
\text { hitung }\end{array}$ & $\begin{array}{l}\text { F } \\
\text { tabel } \\
\mathbf{0 , 0 5}\end{array}$ \\
\hline Perlakuan & 2 & 5,78 & 2,89 & $0,94^{\text {tn }}$ & 4,26 \\
\hline Galat & 9 & 27,61 & 3,06 & \multicolumn{2}{|l}{} \\
\cline { 1 - 4 } Total & 11 & 33,39 & \multicolumn{3}{|l}{} \\
\cline { 1 - 3 } & & & &
\end{tabular}

Keterangan: tn menunjukkan tidak berbeda nyata

Tabel Ringkasan ANAVA ganda tentang 1.3 pengaruh ranggas paksa metode puasa dan suplementasi tepung bekicot terhadap jumlah folikel yolk kecil

\begin{tabular}{|c|c|c|c|c|c|}
\hline SK & db & JK & KT & $\begin{array}{c}\text { F } \\
\text { hitung }\end{array}$ & $\begin{array}{c}F \\
\text { tabel } \\
0,05\end{array}$ \\
\hline Ulangan & 3 & 0,19 & 0,06 & $0,30^{\mathrm{tn}}$ & 3,07 \\
\hline Perlakuan: & (7) & $(1,90)$ & 0,27 & $1,35^{\mathrm{tn}}$ & 2,49 \\
\hline$P$ & 1 & 0,08 & 0,08 & $0,40^{\mathrm{tn}}$ & 4,32 \\
\hline $\mathrm{F}$ & 3 & 0,83 & 0,27 & $1,29^{\mathrm{tn}}$ & 3,07 \\
\hline $\mathrm{PF}$ & 3 & 0,99 & 0,33 & $1,65^{\text {tn }}$ & 3,07 \\
\hline Galat & 21 & 4,39 & 0,20 & & \\
\hline Total & 31 & 6,48 & & & \\
\hline
\end{tabular}

Keterangan: tn menunjukkan tidak berbeda nyata

Tabel Ringkasan ANAVA tunggal tentang 1.4 pengaruh durasi puasa terhadap jumlah folikel yolk berukuran besar

\begin{tabular}{|c|c|c|c|c|c|}
\hline SK & Db & JK & KT & $\begin{array}{l}\text { F } \\
\text { hitung }\end{array}$ & $\begin{array}{l}\text { F } \\
\text { tabel } \\
0,05\end{array}$ \\
\hline Perlakuan & 2 & 0,64 & 0,32 & $1,60^{\mathrm{tn}}$ & 4,26 \\
\hline Galat & 9 & 1,86 & 0,20 & & \\
\hline Total & 11 & 2,50 & & & \\
\hline
\end{tabular}

Keterangan: tn menunjukkan tidak berbeda nyata 
Pengaruh Ranggas Paksa dan Suplementasi ...

Tabel

Ringkasan ANAVA ganda tentang

1.5 pengaruh ranggas paksa metode puasa dan suplementasi tepung bekicot terhadap jumlah folikel yolk berukuran sedang

\begin{tabular}{|c|c|c|c|c|c|}
\hline SK & db & JK & KT & $\begin{array}{c}\text { F } \\
\text { hitung }\end{array}$ & $\begin{array}{c}\mathbf{F} \\
\text { tabel } \\
\mathbf{0 , 0 5}\end{array}$ \\
\hline Ulangan & 3 & 0,11 & 0,03 & $0,23^{\mathrm{tn}}$ & 3,07 \\
\hline Perlakuan: & (7) & $(1,78)$ & 0,25 & $1,92^{\mathrm{tn}}$ & 2,49 \\
\hline $\mathrm{P}$ & 1 & 0,01 & 0,01 & $0,07^{\mathrm{tn}}$ & 4,32 \\
\hline $\mathrm{F}$ & 3 & 0,32 & 0,10 & $0,76^{\mathrm{tn}}$ & 3,07 \\
\hline $\mathrm{PF}$ & 3 & 1,45 & 0,48 & $3,69 *$ & 3,07 \\
\hline Galat & 21 & 2,87 & 0,13 & & \\
\hline Total & 31 & 4,05 & & & \\
\hline
\end{tabular}

Ket: tn menunjukkan tidak berbeda nyata

* menunjukkan berbeda nyata

Tabel

Ringkasan BNT 0,05 tentang pengaruh 1.6 ranggas paksa metode puasa dan suplementasi tepung bekicot terhadap jumlah folikel yolk berukuran sedang

\begin{tabular}{|c|c|c|}
\hline Perlakuan & Rata-rata & Notasi \\
\hline P1F2 & 0,92 & $\mathrm{a}$ \\
\hline P2F0 & 0,92 & $\mathrm{a}$ \\
\hline P1F1 & 1,18 & $\mathrm{ab}$ \\
\hline P1F3 & 1,18 & $\mathrm{ab}$ \\
\hline P2F1 & 1,27 & $\mathrm{ab}$ \\
\hline P2F2 & 1,27 & $\mathrm{ab}$ \\
\hline P1F0 & 1,58 & $\mathrm{~b}$ \\
\hline P2F3 & 1,58 & $\mathrm{~b}$ \\
\hline
\end{tabular}

Keterangan: Angka yang didampingi dengan huruf yang sama pada kolom yang sama tidak berbeda nyata pada taraf signifikan 0,05 .
Tabel Ringkasan ANAVA tunggal tentang 1.7 pengaruh durasi puasa terhadap jumlah folikel yolk berukuran sedang

\begin{tabular}{|l|l|l|l|l|l|}
\hline SK & Db & JK & KT & $\begin{array}{l}\text { F } \\
\text { hitung }\end{array}$ & $\begin{array}{l}\text { F } \\
\text { tabel } \\
\mathbf{0 , 0 5}\end{array}$ \\
\hline Perlakuan & 2 & 1,10 & 0,55 & $6,11^{*}$ & 4,26 \\
\hline Galat & 9 & 0,83 & 0,09 & & \\
\cline { 1 - 3 } Total & 11 & 2,94 & \multicolumn{3}{l}{} \\
Keterangan: * menunjukkan berbeda nyata
\end{tabular}

Tabel Ringkasan BNT 0,05 tentang pengaruh 1.8 durasi puasa terhadap jumlah folikel yolk berukuran sedang

\begin{tabular}{|c|c|c|}
\hline Perlakuan & Rata-rata & Notasi \\
\hline P2F0 & 0,92 & $\mathrm{a}$ \\
\hline P0F0 & 0,96 & $\mathrm{a}$ \\
\hline P1F0 & 1,58 & $\mathrm{~b}$ \\
\hline
\end{tabular}

Keterangan: Angka yang didampingi dengan huruf yang sama pada kolom yang sama tidak berbeda nyata pada taraf signifikan 0,05 .

Tabel Ringkasan ANAVA ganda tentang 1.9 pengaruh ranggas paksa metode puasa dan suplementasi tepung bekicot terhadap jumlah folikel yolk berukuran kecil

\begin{tabular}{|l|l|l|l|l|l|}
\hline \multicolumn{1}{|c|}{ SK } & db & \multicolumn{1}{|c|}{ JK } & KT & \multicolumn{1}{|c|}{$\begin{array}{c}\text { F } \\
\text { hitun } \\
\mathbf{g}\end{array}$} & $\begin{array}{c}\text { tabe } \\
\mathbf{l} \\
\mathbf{0 , 0 5}\end{array}$ \\
\hline Ulangan & 3 & 9,22 & 3,07 & $2,17^{\text {tn }}$ & 3,07 \\
\hline $\begin{array}{l}\text { Perlakuan } \\
:\end{array}$ & $(7$ & $(31,89$ & 4,56 & $3,23^{*}$ & 2,49 \\
\hline P & 1 & 17,84 & 17,8 & 12,65 & 4,32 \\
\hline F & 3 & 8,02 & 2,67 & $1,89^{\text {tn }}$ & 3,07 \\
\hline PF & 3 & 6,03 & 2,01 & $1,42^{\text {tn }}$ & 3,07 \\
\hline Galat & 21 & 29,71 & 1,41 & & \\
\hline
\end{tabular}




\begin{tabular}{l|l|l|l}
\hline Total & 31 & 31 & \\
& Keterangan: & \\
& $*$ menunjukkan tidak berbeda nyata \\
& menukan berbeda nyata \\
Tabel & $\begin{array}{l}\text { Ringkasan BNT 0,05 tentang } \\
\text { 1.10 pengaruh perlakuan ranggas paksa }\end{array}$ \\
& $\begin{array}{l}\text { dan suplementasi tepung bekicot } \\
\text { terhadap jumlah folikel yolk } \\
\text { berukuran kecil }\end{array}$
\end{tabular}

\begin{tabular}{|c|c|c|}
\hline Perlakuan & Rata-rata & Notasi \\
\hline P1F2 & 0,92 & a \\
\hline P1F1 & 2,81 & b \\
\hline P1F0 & 2,86 & b \\
\hline P1F3 & 3,19 & b \\
\hline P2F0 & 3,56 & b \\
\hline P2F2 & 3,81 & b \\
\hline P2F3 & 4,03 & b \\
\hline P2F1 & 4,32 & b \\
\hline
\end{tabular}

Keterangan: Angka yang didampingi dengan huruf yang sama pada kolom yang sama tidak berbeda nyata pada taraf signifikan 0,05

Tabel Ringkasan ANAVA tunggal tentang 1.11 pengaruh durasi puasa terhadap jumlah folikel yolk berukuran kecil

\begin{tabular}{|l|l|l|l|l|l|}
\hline SK & Db & JK & KT & $\begin{array}{l}\text { F } \\
\text { hitung }\end{array}$ & $\begin{array}{l}\text { F } \\
\text { tabel } \\
\mathbf{0 , 0 5}\end{array}$ \\
\hline Perlakuan & 2 & 1,45 & 0,73 & $0,81^{\text {tn }}$ & 4,26 \\
\hline Galat & 9 & 8,11 & 0,90 & \\
\cline { 1 - 3 } Total & 11 & 9,56 & \multicolumn{5}{l}{} \\
Keterangan: tn menjukkan tidak berbeda nyata
\end{tabular}

Keterangan: tn menunjukkan tidak berbeda nyata

\section{PEMBAHASAN}

Berdasarkan tabel 1.1 dapat diketahui bahwa kombinasi perlakuan ranggas paksa (puasa pakan selama 72 jam dan 168 jam) dengan suplementasi tepung bekicot $(0 \%, 6 \%, 12 \%$ dan $18 \%)$ pada ransum memberikan hasil tidak berbeda nyata dalam meningkatkan bobot ovarium. Hal ini diduga perlakuan puasa pakan selama 72 jam dan 168 jam mampu mengurangi sekresi vasoactive intestinal polypeptide (VIP) dari hipotalamus. Sekresi VIP yang berkurang menyebabkan stimulasi terhadap sekresi hormon prolaktin dari pituitari anterior tidak mencukupi, akibatnya sekresi hormon prolaktin menurun.

Penurunan sekresi hormon prolaktin menyebabkan peningkatan sekresi hormon FSH dan LH dari pituitari anterior. Hormon FSH menstimulasi pertumbuhan folikel yolk dan hormon LH berperan dalam proses ovulasi folikel yolk dari ovarium, sehingga merangsang ovarium untuk memperbanyak folikel bukan menumbuhkembangkan folikel yang telah terbentuk, sehingga tidak mengalami peningkatan bobot ovarium.

Kehadiran suplementasi tepung bekicot tidak mempengaruhi bobot ovarium, diduga kandungan protein pada ransum tanpa suplementasi tepung bekicot sudah mencukupi kebutuhan protein ayam sebagai sumber hormon dan bahan penyusun yolk dalam proses regenerasi ovarium. Konsumsi protein yang meningkat tidak sepenuhnya 
Pengaruh Ranggas Paksa dan Suplementasi ...

dimanfaatkan oleh tubuh karena melebihi kebutuhan. Kelebihan konsumsi protein akan didegradasi menjadi sumber energi dan amonia yang dikeluarkan bersama feces (Suprijatna et al., 2006).

Pada penelitian ini menunjukkan bahwa perlakuan ranggas paksa metode puasa mampu mengembalikan regenerasi ovarium yang melibatkan pertumbuhan folikel yolk memasuki periode molting. Hal ini dapat diamati melalui munculnya folikel-folikel kecil yang ternyata menghambat pertumbuhan folikel besar. Hadirnya hambatan ini mengakibatkan bobot ovarium tidak mengalami peningkatan. Hasil penelitian ini sejalan dengan penelitian Oguike et al. (2005), yang menunjukkan bahwa bobot ovarium ayam yang diranggas paksa dengan berbagai jenis metode puasa tidak berbeda nyata ketika diukur 35 hari setelah diberi pakan. Hal ini menunjukkan bahwa 35 hari setelah perlakuan ranggas paksa diduga merupakan masa awal regenerasi ovarium sehingga pertumbuhan folikel yolk belum optimal.

Dari hasil penelitian ini diketahui bahwa semakin lama ayam mengalami ranggas paksa, maka semakin efektif mengurangi sekresi VIP. Ayam yang mendapat perlakuan ranggas paksa mengalami penurunan kadar hormon prolaktin yang berakibat terhadap sekresi hormon gonadotropin (Berry, 2003). Pada saat periode molting sekresi VIP mencapai 50-60 $\mathrm{ng} / \mathrm{ml}$ dan saat periode layer 30-40 $\mathrm{ng} / \mathrm{ml}$. Hormon prolaktin saat periode molting mencapai 400-500 ng/ml dan saat periode layer kurang dari 100 ng/ml (Kuenzel, 2003).

Proses regenerasi organ reproduksi yang melibatkan pertumbuhan folikel yolk dipengaruhi oleh kerja hormon FSH dan LH. Hormon FSH dan LH mengalami penurunan ketika ayam diranggas paksa dan kembali meningkat setelah perlakuan. Gjorgovska et al.(2008) melaporkan, kadar hormon FSH dalam plasma darah saat perlakuan ranggas paksa 25,16 ng/ml, 10 hari dan 20 hari setelah perlakuan masing-masing 60,41 ng/ml dan 61,62 ng/ml. Kadar hormon LH dalam plasma darah saat perlakuan ranggas paksa 2,08 ng/ml, 10 hari dan 20 hari setelah perlakuan masingmasing 5,71 ng/ml dan 12,64 ng/ml. Hal ini menunjukkan bahwa 20 hari setelah perlakuan ranggas paksa sekresi hormon gonadotropin masih belum optimal 
seperti saat periode layer yaitu FSH 64,26 ng/ml dan LH 27,76 ng/ml.

Ovarium mulai regenerasi pada hari ke-21 setelah perlakuan ranggas paksa, hal ini diketahui banyaknya folikel yolk yang mulai tumbuh. Konsentrasi hormon progesteron mulai meningkat seiring dengan pertumbuhan folikel yolk. Kadar hormon progesteron pada plasma darah sebanyak $0,40 \mathrm{ng} / \mathrm{ml}$ pada hari ke-21 setelah ayam diberi pakan, kemudian mengalami peningkatan pada hari ke-35 mencapai 0,50 ng/ml dan pada hari ke-56 mencapai 1,01 ng/ml (Oguike et al., 2005). Berdasarkan hal tersebut, diketahui bahwa peningkatan kadar hormon progesteron dapat dijadikan tolak ukur regenerasi ovarium yang melibatkan pertumbuhan folikel yolk.

Pada saat ranggas paksa ayam mengalami penurunan bobot badan akibat regresi dari hati, ovarium, oviduk, jaringan adiposa dan jaringan otot (Berry, 2003). Bobot ovarium mengalami penurunan mencapai $80 \%$ dan bobot oviduk 65\% (Hasan et al., 2000). Penurunan bobot badan akibat pemanfatan jaringan lemak pada tubuh untuk efesiensi jaringan (Alodan dan Mashaly, 1999). Regresi pada organ reproduksi memberikan pengaruh positif untuk memberikan waktu istirahat yang bertujuan untuk mempertahankan kesehatan dan kondisi sistem reproduksi ayam (Khajali et al., 2008).

Proses regenerasi organ reproduksi setelah perlakuan ranggas paksa dapat dipercepat dengan penambahan crud protein pada ransum (Togun et al., 2004). Pada penelitian ini suplementasi tepung bekicot pada ransum bertujuan untuk meningkatkan jumlah protein yang dikonsumsi oleh ayam sehingga dapat mempercepat proses pertumbuhan folikel yolk pada ovarium. Dari hasil penelitian ini menunjukkan bahwa suplementasi tepung bekicot tidak berpengaruh terhadap bobot ovarium sebagaimana tercantum dalam tabel 1.1.

Bobot ovarium dipengaruhi mekanisme pertumbuhan dan ovulasi folikel yolk. Mekanisme pertumbuhan dan ovulasi folikel yolk pada ayam diatur oleh hormon FSH, LH dan hormon yang dihasilkan ovarium. Enam jam sebelum folikel yolk diovulasikan hormon LH mengalami peningkatan. Peningkatan hormon LH menstimulasi sekresi hormon estrogen dan progesteron. Peningkatan hormon estrogen mengontrol transfer bahan yolk 
Pengaruh Ranggas Paksa dan Suplementasi ...

ke folikel besar untuk mencapai ukuran optimal. Hormon estrogen yang tinggi menyebabkan umpan balik negatif terhadap sekresi FSH sehingga untuk sementara pertumbuhan folikel yolk kecil dan sedang dihambat. Peningkatan hormon progesteron menyebabkan umpan balik positif terhadap sekresi hormon LH. Sekresi hormon LH yang tinggi berperan dalam proses ovulasi dengan merobek membran vetilen pada bagian stigma sehingga ovum bisa diovulasikan dari ovarium. Setelah ovum diovulasikan hormon LH mengalami penurunan sedangkan sekresi hormon FSH kembali meningkat untuk melanjutkan kembali pertumbuhan folikel yolk (Yuwanta, 2004; Robinson dan Renema, 2009).

$$
\text { Pengaruh lain yang }
$$
menyebabkan suplementasi tepung bekicot memberikan hasil tidak nyata adalah kandungan protein kasar pada ransum. Ransum tanpa suplementasi tepung bekicot mengandung 16,22\% protein kasar dan suplementasi tepung bekicot sebanyak 20\% mengandung $17,26 \%$ protein kasar (Sa'adah, 2008). Hal tersebut menunjukkan bahwa kadar protein pada ransum melebihi kebutuhan protein ayam (Gallus turcicus).
Suprijatna dkk

(2006) melaporkan bahwa taraf protein kasar $12 \%$ pada ransum sudah optimal dalam meningkatkan pertumbuhan ayam untuk mencapai puncak produksi telur. Hal ini menunjukkan bahwa ayam kurang responsif terhadap peningkatan taraf protein yang lebih tinggi dari $12 \%$. Konsumsi protein yang meningkat tidak disintesis menjadi jaringan tubuh, karena telah melebihi kebutuhan. Kelebihan konsumsi protein akan didegradasi menjadi sumber energi dan amonia yang diekresi lewat feces.

Menurut Komariah

(2009)

kelebihan konsumsi protein yang menyebabkan peningkatan asam amino dalam tubuh tidak disimpan melainkan mengalami katabolisme menjadi energi berupa ATP. Zuprizal (2008) menambahkan, kelebihan asam amino dalam tubuh akan mengalami eleminasi dan dikeluarkan dari dalam tubuh. Untuk mengeliminasi kelebihan asam amino di dalam tubuh menggunakan sebagian besar energi metabolis. Pada ternak unggas, kelebihan asam amino tidak digunakan oleh tubuh dalam penambahan bobot badan atau produksi telur melainkan dikeluarkan bersama feces setelah didegradasi. 
Degradasi asam amino menjadi energi terjadi di hati dimulai dengan proses deaminasi. Deaminasi yaitu proses pembuangan gugus amino dari asam amino. Gugus amino dari asam amino dipindahkan ke asam alfa ketoglutarat yang kemudian menjadi asam glutamat. Asam glutamat kemudian melepaskan gugus amino dalam bentuk amonia. Amonia yang dilepaskan waktu deaminasi dikeluarkan dari darah dalam bentuk urea. Setelah asam amino mengalami deaminasi, asam keto yang dihasilkan dioksidasi untuk menghasilkan energi.

\section{KESIMPULAN}

Hasil penelitian menunjukkan bahwa perlakuan ranggas paksa metode puasa dan suplementasi tepung bekicot terhadap pertumbuhan folikel yolk ayam (Gallus turcicus) yang ditinjau dari bobot ovarium dan jumlah folikel yolk berukuran besar, sedang, dan kecil tidak sepenuhnya tercapai. Fenomena ini terungkap pada data yang terkait dengan ranggas paksa dan suplementasi tepung bekicot tidak berpengaruh terhadap bobot folikel ovarium dan jumlah folikel besar, tetapi berpengaruh terhadap jumlah folikel yolk berukuran kecil dan sedang, karena ransum standar yang tersusun dari jagung, bekatul, tepung ikan, tepung bungkil kacang dan topmix sudah mencukupi kebutuhan nutrien ayam. Dari hasil penelitian ini terungkap bahwa kehadiran tepung bekicot tidak memberikan pengaruh sepenuhnya terhadap perannya sebagai suplemen, tetapi mungkin sebagai pengganti tepung ikan. Dengan demikian perlu dilakukan penelitian lanjutan tentang tepung bekicot sebagai pengganti tepung ikan.

\section{UCAPAN TERIMA KASIH:}

Penulis mengucapkan terimakasih kepada:

1. Dr. Ulfah Utami, M. Si selaku ketua Lemlitbang (Lembaga Penelitian dan Pengembangan) Universitas Islam Negeri Maulana Malik Ibrahim Malang yang telah memberikan motivasi dan dana hibah penelitian DIPA tahun anggaran 2010.

2. Suyono, M. P selaku Koordinator Laboratorium Jurusan Biologi yang telah memberikan ijin untuk menggunakan fasilitas laboratorium selama penelitian berlangsung. 
3. M. Basyarudin, S.Si selaku Laboran Jurusan Biologi yang telah membantu menyiapkan alat-alat laboratorium.

\section{DAFTAR PUSTAKA}

Alodan, M. A dan Mashaly, M. M. 1999. Effect of Induced Molting in Laying Hens on Production and Immune Parameters. Poultry Science. 78: 171-177.

Berry, W. D. 2003. The Physiology of Induced Molting. Poultry Science. 82: 971-980.

Brake, J., Bell, D., Beard, C., dan Waters, G. 1998. Induced Molting in the U. S. Commercial Layer Industry. Poultry \& Egg Association. Pp 1-3.

Darmana, W. dan Sitanggang, M. 2002. Meningkatkan Produktifitas Ayam Arab Petelur. Jakarta: Agromedia Pustaka. Hlm 1-3

Gjorgovska, N., Filev, K., dan Konakchieva, R. 2008. Influence of Induced Molting on Hormonal Status of Aged Laying Hens. Karmiva. 50 (1): 19-25.

Hasan, Z. U., Sultan, J. V., dan Akram, M. 2000. Nutritional Manipulations During Induced Moult in White Leghorn Layer 2. Effecs on Per Cent Hen Day Egg Production, Body Weight and Reproductive System. International Journal of Agriculture \& Biology. 2(4): 318321.
Khajali, F., Karimi, S., dan Akhari, M. R. 2008. Physiological Response and Posmolt Performance of Laying Hens Molted by Non-Feed Removal Metods. American Journal of Animal and Veterinary Sciences. 3(1): 13-17.

Komariah, 2009. Metabolisme Protein. Bandung: Makalah Ilmiah Universitas Padjajdjaran. HIm 7.

Kuenzel, W. J. 2003. Neurobiology of Molt in Avian Species. Poultry Science. 82: 981-991.

Malik, H. M., Haq, E. U. dan Ahmad, F. 2008. Effect of Age and Body Weight At Molting on the Performance of Broiler Breeder Hens Under Environmental Control Houses in Pakistan. Pakistan Vet. J. 28 (4): 189-193.

Offiong, S. A., Ekpo, F. U., Obasi, O. L., dan Ojebiyi, O. O. 2006. Evolution of Some Methods of Forced-Moult Performance and Quality Characteristics of the Post-Moult Eggs. Agricultural Journal, 1(3): 160-166.

Oguike, M. A., Igboeli, G., Ibe, S.N., Iromkwe, M.O., Akomas, S.C. dan Uzoukwu, M. 2005. Plasma Progesterone Profile and Ovarian Activity of Forced-Moult Layers. African Journal of Biotechnology, 4(9): 1005-1009.

Robinson, F. E., dan Renema, R. A. 2009. Female Reproduction: Control of Ovarian Functionhttp://spottedcowpress.ca /chapters/02FemaleAnatomy.pdf. Diakses tanggal 30 November 2009. Pp 3-10. 
Sa'adah, Anis. 2008. Pengaruh Pemberian Tepung Bekicot (Achatina fulica) Sebagai Subtitusi Tepung Ikan di Dalam Ransum Terhadap Produksi dan Kualitas Telur Pada Burung Puyuh (Coturnix coturnix japonica). Skripsi. Tidak Diterbitkan. Malang: Jurusan Biologi Fakultas Sains dan Teknologi Universitas Islam Negeri (UIN) Maulana Malik Ibrahim Malang. hlm 20-35.

Suprijatna, E., Atmomarsono, U., dan Kartasudjana, R. 2005. Ilmu Dasar Ternak Unggas. Jakarta: Penebar Swadaya. hlm 57-59.

Taixeira, R. S. C., Cardoso, W. M., Nogueira, G. C., Camara, S. R., Romao, J. M., Siqueira, A. A., Sampaio, F. A. C., Moraes, T. G. V., Campello C. C., dan Buxade, C. C. 2007. Evaluation of Induced Molting Methods on the Livability and Reproductive System Regression of Japanese Quails (Coturnix japonica). Brazilian Journal of Poultry Science. 9(2): 85-89.

Togun, V. A., Okwusidi, J. I., Amao, O. A., dan Onyiaoha, S. U. 2004. Effect of Crude Protein Levels and Follicle Stimulation on Egg Production Of Age Hens. Nigerian Journal of Physiological Sciences. 19 (1-2): 77-81.

Webster, A. B. 2003. Physiology and Behavior of the Hen During Induced Molt. Poultry Science. 82(6): 992-1002.

Yuwanta, T. 2004. Dasar Ternak Unggas. Yogyakarta: Kanisius. hlm 85-110.
Zuprizal. 2009. Industri Pakan Ternak Unggas di Indonesia: Tinjauan Dari Penggunaan Makronutrien Protein Pakan. Pidato Pengukuhan Jabatan Guru Besar pada Fakultas Peternakan Universitas Gadjah Mada: UGM Yogyakarta. hlm 10-11. 